\title{
The South Armenian block, Lesser \\ Caucasus, Tethyan metallogenic belt: a favorable tectonic zone for high Au endowment during Cenozoic closure of the southern Neotethys
}

\author{
MARION GROSJEAN ${ }^{1}$, ROBERT MORITZ ${ }^{1}$, HERVÉ \\ REZEAU $^{2}$, SAMVEL HOVAKIMYAN ${ }^{1,3}$ AND RAFAEL \\ MELKONYAN ${ }^{3}$
}

${ }^{1}$ University of Geneva

${ }^{2}$ MIT

${ }^{3}$ National Academy of Sciences

Presenting Author: marion.grosjean@unige.ch

The Gondwana-derived South Armenian Block (SAB) is located at $\sim 250$ to $500 \mathrm{~km}$ from the Bitlis-Zagros suture zone, at the merging location of the EW-oriented Turkish subduction zone with the NW-oriented Iranian subduction zone. The magmatic rocks located in the $\mathrm{SAB}$ have the most radiogenic $\mathrm{Nd}$ isotope ratios, revealing the most juvenile mantle component $(\varepsilon N d(i)>2)$ among all Cenozoic magmatic rocks related to southern Neotethys subduction and Arabian collision, including in the neighboring Turkish and Iranian tectonic zones. The mantle anomaly in the $\mathrm{SAB}$ is attributed to asthenospheric mantle upwelling, as a result of post-collisional roll back and/or tearing of the subducted lithosphere within the pronounced arcuate geometry accommodating subduction along strike from Turkey to Iran. We suggest that the asthenospheric upwelling resulted in a low degree of partial melting of a metasomatized lithosphere, which sourced high-K calc-alkaline to shoshonitic magmatic rocks emplaced in the SAB between $\sim 42 \mathrm{Ma}$ and $\sim 21$ Ma.

The magmatism initiated in the NW of the SAB (Tejsar massif), and with time migrated toward the SE, along the NWSE-trending Pambak- Sevan -Sunik dextral strike- slip fault zone in a transtensional geodynamic environment. In parallel, spatially and temporally associated epithermal Au (e.g. from NW to SE: Meghradzor(0.38Mt@12.4g/tAu),Zod/Sotk (23Mt @ 7.0 g/t $\mathrm{Au}$ ), Amulsar (102Mt@0.79g/t Au) and porphyry Cu-Mo deposits (e.g., Kadjaran (2244Mt@0.23\% Cu, 0.033\%Mo, $0.02 \mathrm{~g} / \mathrm{t} \mathrm{Au}$ ) emplaced. Numerous Au prospects of the same age are also present, resulting in a high abundance of $\mathrm{Au}$ deposits and occurrences in the SAB, temporally and spatially associated to alkaline magmatic rocks, which are isotopically characterized by a juvenile mantle composition. Our study demonstrates the link of this magma type with the genesis of precious metal epithermal and porphyry deposits in the Central Tethyan metallogenic belt.

The SAB is interpreted as a highly prospective area in terms of $\mathrm{Au}$ exploration, with many favorable ore locations concealed by late Neogene to Quaternary volcanic and sedimentary rocks. A regional comparison of ore grade and tonnage of the deposits vs. alkalinity of their host rocks might allow us to better understand the $\mathrm{Au}$ endowment of this region. 